\title{
URGENSI BIMBINGAN KONSELING BAGI PIAUD
}

\author{
Linda Rohamtul Jannah, Dwi Bhakti Indri M. \\ Institut Pesantren KH. Abdul Chalim Mojokerto \\ lindarj675@gmail.com, indrimdwibhakti@gmail.com
}

\begin{abstract}
ABSTRAK
Pengetahuan tentang bimbingan konseling sangatlah penting bagi guru atau pendamping pendidikan islam anak usia dini, yang meliputi karakteristik perkembangan anak usia dini, pendekatan perkembangan dalam bimbingan dan konseling serta pengembangan program bimbingan dan konseling untuk anak usia dini. Upaya mencerdaskan anak sewajarnya dilakukan sedini mungkin, agar anak tumbuh dan berkembang sebagai individu yang cerdas baik secara intelektual, emosional maupun spiritual. Selanjutnya, secara dini pula orang dewasa (guru dan orang tua) perlu memahami dan membantu membimbing anak agar berbagai aspek perkembangan, seperti fase dan tugas perkembangan mereka dapat tumbuh dan berkembang secara optimal. Dalam kajian lain diungkapkan bahwa sekitar 50\% kapabilitas kecerdasan manusia terjadi ketika anak berumur 4 tahun, $80 \%$ telah terjadi ketika berumur 8 tahun, dan mencapai titik kulminasi ketika anak berumur sekitar 18 tahun. Hal ini berarti bahwa perkembangan yang terjadi dalam kurun waktu 4 tahun pertama sama besarnya dengan perkembangan yang terjadi pada kurun waktu 14 tahun berikutnya, dan selanjutnya perkembangan otak akan mengalami stagnasi. Itulah sebabnya periode ini dinamakan usia emas (golden age) dan setelah perkembangan ini lewat maka berapa pun kapabilitas kecerdasan yang dicapai individu, tidak akan mengalami peningkatan lagi atau dengan kata lain tidak memiliki kebermaknaan. Kegiatan bimbingan dan konseling untuk anak usia dini diarahkan untuk membantu anak agar dapat bersosialisasi dengan teman-temannya di sekolah (Play Group, TK, TPA). Misalnya, pada saat awal masuk sekolah umumnya anak-anak mengalami kesulitan bersosialisasi maka dengan bantuan guru/pembimbing anak dikenalkan dengan teman-temannya yang lain dalam suasana yang menyenangkan, menggembirakan dan mengasyikkan. Kegiatan bimbingan dan konseling untuk anak usia dini juga dilaksanakan sebagai upaya membantu anakanak agar dapat mengembangkan dan mengelola aspek afeksi anak. Misalnya, menumbuhkan kecintaan terhadap lingkungan alam sekitar sekolah.
\end{abstract}

Kata Kunci : Bimbingan Konseling, Pendidikan Islam Anak Usia Dini.

\section{PENDAHULUAN}

Terdapat beberapa alasan yang memperkuat pemikiran tersebut di atas, pertama laporan hasil analisis Tim Education for all (Pendidikan untuk semua) Indonesia tahun 2000, yang berpangkalan di Departemen Pendidikan Nasional disebutkan bahwa pada tahun 2000 dari sekitar 26 juta anak Indonesia usia 0-6 tahun, lebih dari $80 \%$ anak Indonesia belum mendapatkan layanan pendidikan anak usia dini. Khususnya anak usia 4-6 tahun yang berjumlah 12 juta, baru sekitar 2 juta yang terlayani di Taman Kanak-kanak (TK) dan Raudatul Athfal (RA) (Gutama, 2002:33).

Kedua, hasil penelitian yang menyebutkan bahwa masa usia dini adalah periode kritis dalam 
perkembangan anak. Hasil kajian neurologi menunjukkan bahwa pada saat lahir otak bayi membawa potensi sekitar 100 miliar yang pada proses berikutnya sel-sel dalam otak tersebut berkembang $\quad 1.2$ Bimbingan Konseling untuk Pendidikan Islam Anak Usia Dini dengan begitu pesat dengan menghasilkan bertriliuntriliun sambungan antar neuron. Supaya mencapai perkembangan optimal sambungan ini harus

diperkuat melalui berbagai rangsangan psikososial karenasambungan yang tidak diperkuat akan mengalami atropi (penyusutan) dan musnah. Inilah yang pada akhirnya akan mempengaruhi kecerdasan anak. Hal ini telah dibuktikan dengan hasil penelitian di Baylor College of Medicine (Jalal, 2002: 21-25) yang menemukan

bahwa apabila anak jarang memperoleh rangsangan pendidikan maka perkembangan otaknya lebih kecil $20-30 \%$ dari ukuran normal anak seusianya.

Kegiatan bimbingan dan konseling untuk anak usia dini diarahkan untuk membantu anak agar dapat bersosialisasi dengan temantemannya di sekolah (Play Group, TK, TPA). Misalnya, pada saat awal masuk sekolah umumnya anak-anak mengalami kesulitan bersosialisasi maka dengan bantuan guru/pembimbing anak dikenalkan dengan teman-temannya yang lain dalam suasana yang menyenangkan, menggembirakan dan mengasyikkan.

Kegiatan bimbingan dan konseling untuk pendidikan islam anak usia dini juga dilaksanakan sebagai upaya membantu anak-anak agar dapat mengembangkan dan mengelola aspek afeksi anak. 
Pengorganisasian,

penyampaian dan pengelolaan

pembelajaran bimbingan dan konseling pada anak usia dini dapat Anda lakukan lebih efektif dan efisien maka sebagai guru perlu memahami terlebih dahulu pengetahuan tentang hakikat bimbingan dan konseling pada anak usia dini secara utuh berdasarkan ilmu dan teori.

Pokok-pokok materi dalam jurnal ini yaitu : pengertian bimbingan dan konseling pada anak usia dini dan fungsi, sasaran dan ruang lingkup bimbingan dan konseling untuk anak usia dini.

\section{Pengertian Bimbingan Dan Konseling Pada Anak Usia Dini}

Muro \& Kottman (Nurihsan, 2003: 11) memaparkan bahwa bimbingan yang berkembang saat ini adalah bimbingan perkembangan. Visi bimbingan bersifat edukatif,

pengembangan dan outreach. Edukatif karena titik berat layanan

bimbingan ditekankan pada pencegahan dan pengembangan, bukan korektif atau terapeutik, walaupun layanan tersebut juga tidak diabaikan. Pengembangan karena orientasi sasaran bimbingan adalah perkembangan optimal seluruh aspek kepribadian individu dengan upaya

memberikan kemudahan perkembangan melalui perekayasaan lingkungan perkembangan. Outreach karena sasaran populasi layanan bimbingan tidak terbatas kepada individu bermasalah tetapi semua individu berkenaan dengan semua aspek kepribadiannya dalam semua konteks kehidupannya (masalah, target intervensi, setting, metode, dan lama waktu layanan). Teknik

bimbingan yang dipergunakan, meliputi teknik-teknik pembelajaran, 
pertukaran informasi, bermain peran, tutorial, dan konseling.

Shertzer dan Stone (1971:40), mengartikan bimbingan sebagai “... process of helping an individual to understand himself and his world. Artinya proses pemberian bantuan kepada individu agar mampu memahami diri dan lingkungannya". Selanjutnya, Sunaryo (1998: 3), mengartikan sebagai “... proses membantu individu untuk mencapai perkembangan optimal". Selanjutnya, Natawidjaja (1987: 37), mengartikan bimbingan sebagai suatu proses pemberian bantuan kepada individu

yang dilakukan secara berkesinambungan, agar individu tersebut dapat memahami dirinya

sehingga dia dapat sanggup mengarahkan dirinya dan dapat bertindak secara wajar, sesuai dengan tuntutan dan keadaan lingkungan sekolah, keluarga, masyarakat dan kehidupan pada umumnya.

Menurut Crow \& Crow (M. Surya, 1988: 45) bimbingan diartikan sebagai bantuan yang diberikan seseorang baik pria maupun wanita yang memiliki pribadi yang baik dan pendidikan yang memadai kepada seorang individu dari setiap usia untuk menolongnya, mengembangkan kegiatan-kegiatan hidupnya sendiri, membuat pilihan sendiri, dan memikul bebannya sendiri.

Berdasarkan pendapat para ahli tentang konsep bimbingan dan konseling maka bimbingan dan konseling pada anak usia dini dapat diartikan sebagai upaya bantuan yang dilakukan guru/pendamping terhadap anak usia dini agar anak dapat tumbuh dan berkembang secara optimal serta mampu mengatasi permasalahanpermasalahan yang dihadapinya.
Adapun secara khusus layanan bimbingan dan konseling pada anak usia dini dilakukan untuk membantu mereka untuk dapat:

1. lebih mengenal dirinya, kemampuannya, sifatnya, kebiasaannya dan kesenangannya;

2. mengembangkan potensi yang dimilikinya;

3. mengatasi kesulitan-kesulitan yang dihadapinya;

4. menyiapkan perkembangan mental dan sosial anak untuk masuk ke lembaga pendidikan selanjutnya.

Selain itu, ditinjau dari sudut orang tua, kegiatan bimbingan dan konseling pada anak usia dini ini dapat dilakukan untuk:

1. membantu orang tua agar mengerti, memahami dan menerima anak sebagai individu;

2. membantu orang tua dalam mengatasi gangguan emosi pada anak yang ada hubungannya dengan situasi keluarga di rumah;

3. membantu orang tua mengambil keputusan dalam memilih sekolah bagi anaknya sesuai dengan taraf kemampuan kecerdasan, fisik dan indranya;

4. memberikan informasi kepada orang tua untuk memecahkan masalah kesehatan anak.

\section{Fungsi Bimbingan Untuk Anak Usia Dini}

Berdasarkan pengertian dan prinsip-prinsip yang telah dipaparkan pada kegiatan pembelajaran sebelumnya maka layanan bimbingan untuk anak usia dini dapat berfungsi sebagai berikut. 


\section{Fungsi Pemahaman}

Fungsi pemahaman, yaitu usaha bimbingan yang dilakukan guru/pendamping untuk menghasilkan pemahaman yang menyeluruh tentang aspek-aspek sebagai berikut ini.

a. Pemahaman diri anak didik terutama oleh orang tua dan guru

Anak adalah sosok individu yang memiliki berbagai karakteristik yang berbeda satu sama lain, berbeda pula kelebihan dan kelemahannya. Setiap anak memiliki irama perkembangan

masing-masing dan memiliki kapasitas untuk berkembang sesuai dengan kemampuannya.

Upaya bimbingan yang dilakukan pada pendidikan anak usia dini diharapkan mampu memberikan pemahaman tentang berbagai hal yang ada pada diri anak didik.

b. Hambatan atau masalah-masalah yang dihadapi anak Dalam proses perkembangannya, anak usia dini tidak lepas dari berbagai hambatan atau masalah. Apabila hambatan ini dibiarkan maka akan mempengaruhi proses perkembangan anak berikutnya.
Bimbingan untuk anak usia dini berupaya untuk membantu anak mengurangi atau menghilangkan berbagai hambatan yang dihadapi. Dengan bimbingan, orang tua, guru/pendamping dapat memiliki pemahaman tentang berbagai hambatan atau masalah yang dihadapi anak.

c. Lingkungan anak yang mencakup keluarga dan tempat belajar

Lingkungan
sekitar anak yaitu lingkungan keluarga dan tempat belajar anak merupakan lingkungan yang sehari-hari dimasuki anak. Dalam lingkungan-

lingkungan tersebut banyak hal yang turut mempengaruhi tumbuh kembang anak.

d. Lingkungan yang lebih luas di luar rumah dan di luar tempat belajar

Lingkungan yang lebih luas selain lingkungan rumah dan tempat belajar perlu menjadi perhatian guru dan orang tua karena pengaruh media elektronik dan berbagai 
perkembangan yang

terjadi di masyarakat

secara luas akan turut

mempengaruhi

perkembangan anak.

e. Cara-cara

penyesuaian dan

pengembangan diri

Kemampuan

menyesuaikan diri

merupakan suatu

aspek yang perlu

dimiliki oleh anak

usia dini. Luasnya

lingkungan yang akan

dimasuki

anak

menuntut

kemampuan

penyesuaian diri yang

lebih baik dari anak.

Selain dari itu, berbagai tuntutan

yang terjadi di

masyarakat

mendorong anak

untuk lebih mampu mengembangkan

dirinya agar anak dapat berperan secara

lebih baik di

kemudian hari. Upaya

bimbingan pada

pendidikan anak usia

dini dapat

menumbuhkan

pemahaman bagi

guru/pendamping dan

orang tua bagaimana

cara menyesuaikan

diri dan

mengembangkan

kemampuan anak.

\section{Fungsi Pencegahan}

Fungsi Pencegahan, yaitu usaha bimbingan yang menghasilkan tercegahnya anak dari berbagai permasalahan yang dapat

mengganggu, menghambat

ataupun menimbulkan

kesulitan dalam proses

perkembangannya.

Bimbingan untuk anak

usia dini berfungsi

memberikan pencegahan

terhadap berbagai

kemungkinan yang dapat

dialami anak selama proses

perkembangan. Kemungkinan

tersebut dapat berupa masalah

yang berkaitan dengan

kondisi sosial, emosional atau

kemampuan beradaptasi

dengan lingkungan secara

lebih luas. Dalam pelaksanaan

fungsi pencegahan,

guru/pendamping dapat

melakukannya melalui

berbagai teknik, di antaranya

dengan home visit atau

kunjungan rumah.

3. Fungsi Perbaikan

terselesaikannya berbagai hambatan atau kesulitan yang dihadapi anak didik. Kesulitan anak seberapa punkecilnya akan senantiasa mempengaruhi aktivitas dan perkembangan anak.

Bilamana anak mengalami kesulitan, terlihat dari perubahan sikap yang ditunjukkan anak sehari-hari.

Apabila kesulitan anak dibiarkan maka anak akan lebih terganggu aktivitasnya dan akan mempengaruhi proses perkembangan selanjutnya.

Upaya bimbingan juga diarahkan untuk memperbaiki berbagai 
hambatan atau kesulitan yang dihadapi anak.

4. Fungsi Pemeliharaan dan Pengembangan

Fungsi ini merupakan usaha bimbingan yang menghasilkan terpeliharanya dan berkembangnya berbagai potensi dan kondisi positif anak didik dalam rangka perkembangan dirinya secara mantap dan berkelanjutan.

$$
\text { Bimbingan tidak }
$$

hanya diarahkan pada upaya membantu mengurangi berbagai kesulitan yang dihadapi anak didik, tetapi upaya bimbingan juga berfungsi untuk senantiasa memelihara berbagai potensi dan kondisi yang baik yang sudah dimiliki anak. Pemeliharaan ini menjadi penting artinya karena anak perlu selalu berada dalam kondisi kondusif dalam upaya pengembangan dirinya. Selain dari itu, dengan terpeliharanya potensi dan kondisi positif anak, anakperlu

dikembangkan seoptimal mungkin. Upaya bimbingan dalammengembangkan dalam mengembangkan kemampuan anak harus berorientasi pada kemampuan yang dimiliki anak.

Misalnya, anak yang senang dengan kegiatankegiatan alam atau memiliki potensi kecerdasan naturalis dapat dibantu dikembangkan dengan cara-cara sebagai berikut ini.

a. Mengajak anak-anak menikmatidan mengamati alam terbuka. Misalnya, ke pegunungan, sungai atau laut untuk mengidentifikasi jenis bebatuan, rumput, tanaman dan juga hewan-hewan kecil, seperti semut, capung, jangkrik, ulat, kupukupu, kerang.

b. Membantu anak-anak untuk membiasakan menyiramdan merawat tanaman, menanam biji-bijian dalam media yang mudah dan mengamati pertumbuhannya,

c. Untuk membiasakan membuang sampah, buang air kecil dan besar pada tempatnya beserta cara membersihkannya, Guru/pendamping dapatmengadakan permainan dan program pembelajaran yang berkaitan dengan unsur-unsur alam, seperti membandingkan berbagai bentuk daun dan bunga, mengamati perbedaantekstur pasir,tanahdan kerikil,mengoleksi biji-bijian dan menirukan karakteristik binatang tertentu.

d. Dapat juga menyediakan bukubuku dan VCD yang memuat seluk-beluk hewan, alam, dan tumbuhan dengan gambar-gambar yang bagus dan menarik. 
e. Tidak salah jika kita mengajak anak-anak untuk berkunjung ke tempat-tempat bekas bencana alam, seperti tanah longsor, hutan gundul, gempa dan tsunami, pendangkalan sungai, luapan lumpur panas ataupun abrasi di pantai sehingga anakanak memiliki rasa mencintaidan motivasiuntuk memelihara dan menjaga lingkungan.

\section{Pentingnya BK bagi PIAUD}

Program bimbingan dan konseling di lembaga PAUD merupakan program bimbingan yang bermanfaat secara positif, tidak sekadar reaktif dan korektif. Terlebih lagi, jika program bimbingan ini bersifat kontinum berkelanjutan, dan terusmenerus, mulai dari PAUD hingga perguruan tinggi, bahkan sampai dimasyarakat. Tentu, hasilnya akan jauh lebih baik daripada bimbingan yang sifatnya eksidental semata.

Tetapi, penekanan bimbingan dan konseling dapat berubahubah, sesuai dengan kebutuhan anak didiknya atau sesuai dengan taraf perkembangannya. Atas dasar ini, maka bimbingan konseling di PAUD tidak boleh hanya terfokus pada tumbuh kembangnya anak secara normal dan kompetensi calistung semata, melainkan juga harus menemukan jati diri anak didik yang unik dan khas, sesuai dengan kepribadiannya.

Petualangan pencarian jati diri anak didik harus dimulai sejak dini atau dilembaga PAUD.

Sebab, penemuan dan pemahaman akan dirinya sendiri akan sangat membantu mereka dalam menyesuaikan diri dengan lingkunganlingkungan baru yang akan dihadapi. Disamping itu, penemuan jati diri atau kepribadian anak didik dapat membantu mereka dalam

mengembangkan bakat, minat, dan potensinya.

Perlu ditegaskan disini

bahwa bimbingan dan konseling di lembaga PAUD tidak hanya diberikan kepada mereka yang mempunyai perilaku bermasalah, melainkan juga harus diberikan kepada mereka yang

sedang dalam proses pertumbuhan dan perkembangan. Dengan demikian, konseling bukan hanya untuk mengatasi perilaku bermasalah pada anak didik, melainkan juga tindakan untuk memenuhi

kebutuhan tumbuh kembangnya anak secara maksimal. Pandangan ini menitik beratkan pada bimbingan yang bersifat preventif, kesehatan mental, dan pengembangan diri daripada bimbingan yang menitik beratan pada psikoterapi maupun diagnosis terhadap perilaku bermasalah. Terlebih lagi, ketika para psikolog telah menyadari betapa pentingnya melakukan 
identifikasi sejak dini terhadap perilaku bermasalah pada anak-anak. Dengan melakukan identifikasi ini, diharapkan anak-anak dimasa depan tidak lagi mengalami hambatan dalam belajarnya, terlebih lagi gangguan pada mentalnya.

Momen yang paling tepat untuk melakukan tindakan identifikasi ini adalah pada masa-masa awal usia dini atau di lembaga PAUD. Beberapa alasan berikut ini kiranya dapat memberi pemahaman kepada kita mengapa tindakan identifikasi untuk mencegah perilaku bermasalah paling tepat dilakukan pada masa usia dini atau PAUD.

\section{PENUTUP}

\section{Kesimpulan}

Kegiatan bimbingan menurut para ahli adalah bermuara pada suatu upaya memberikan bantuan kepada individu agar dapat tumbuh dan berkembang secara optimal, sedangkan bimbingan untuk anak usia dini dapat dimaknai sebagai bantuan yang dilakukan guru/pendamping terhadap anak usia dini supaya

mereka dapat tumbuh dan berkembang secara optimal serta mampu mengatasi permasalahanpermasalahan yang dihadapinya.

Pada kegiatan bimbingan untuk anak usia dini memiliki berbagai fungsi, seperti (1) fungsi pemahaman, yaitu usaha bimbingan yang dilakukan guru/pendamping untuk menghasilkan pemahaman yang menyeluruh tentang aspekaspek terkait dengan pemahaman anak didik terutama oleh orang tua, hambatan atau masalah-masalah yang dihadapi anak, lingkungan anak yang mencakup keluarga dan tempat belajar, lingkungan yang lebih luas di luar rumah dan di luar tempat belajar,

cara-cara penyesuaian dan pengembangan diri; (2) fungsi pencegahan, yaitu usaha bimbingan yang menghasilkan tercegahnya anak dari berbagai permasalahan yang dapat mengganggu, menghambat ataupun menimbulkan kesulitan dalam proses perkembangannya; (3) fungsi perbaikan, yaitu usaha bimbingan yang akan menghasilkan terpecahkannya berbagai permasalahan yang dialami oleh anak didik. Fungsi perbaikan ini diarahkan pada terselesaikannya berbagai hambatan atau kesulitan yang dihadapi anak didik; dan (4) fungsi pemeliharaan dan pengembangan, yaitu usaha bimbingan yang menghasilkan terpeliharanya dan berkembangnya berbagai potensi dan kondisi positif anak didik dalam rangka perkembangan dirinya secara mantap dan berkelanjutan.

Secara sederhana setelah membahas kajian mengenai perlunya bimbingan dan konseling di lembaga PAUD, penulis mempunyai tiga prinsip yang dapat digunakan secara umum yang harus dimiliki oleh para konselor di lembaga PAUD. Dan bila ketiganya dapat direalisasikan dalam pelaksanaannya maka kemungkinan besar konseling dapat berjalan dengan baik dan tujuan konseling dapat tercapai sesuai harapan.

\section{Saran}

Penulis telah mencoba mencurahkan semaksimal mungkin usaha dalam menyelesaikan artikel ini, namun penulis menyadari bahwa dalam penulisan artikel ini masih jauh dari kata sempurna. 
DAFTAR RUJUKAN

Syaodih, Emawulan. 2014. Bimbingan Konseling Untuk Anak Usia Dini. Tanggerang Selatan : Universitas Terbuka.

(https://www.kompasiana.com/2ky/5 a268498c2751d6780555c12/pen tingnya-bk-di-sekolah, diakses pada 15 April 2018). 